\title{
Hubungan Profil Lipid dan Derajat Keparahan Penyakit berdasarkan Skor Pediatric Logistic Organ Dysfunction-2 pada Anak dengan Sepsis
}

Rince Restiviona, Chairul Yoel, Pertin Sianturi

Departemen Ilmu Kesehatan Anak Fakultas Kedokteran Universitas Sumatera Utara/RSUP Haji Adam Malik, Medan

Latar belakang. Sepsis adalah penyebab kematian terbanyak pada bayi dan anak di rumah sakit. Sepsis dan syok septik menyebabkan perubahan neuroendokrin dan metabolik termasuk konsentrasi dan komposisi lipid plasma serta lipoprotein. Namun hubungan profil lipid dan derajat keparahan penyakit pada anak dengan sepsis masih belum jelas.

Tujuan. Mengetahui cut-off profil lipid pada pasien anak dengan sepsis dan hubungan profil lipid terhadap derajat keparahan penyakit pada anak dengan sepsis.

Metode. Penelitian potong-lintang bulan Juli sampai Oktober 2017 di PICU, RSUP Haji Adam Malik. Sampel adalah anak usia 1 bulan sampai $<18$ tahun yang didiagnosis sepsis. Pasien yang menderita diabetes melitus, sindrom nefrotik, gizi lebih, gizi buruk, mendapatkan terapi statin dan insulin diekslusikan. Didapatkan 30 orang anak yang memenuhi kriteria. Derajat keparahan penyakit dinilai berdasarkan skor PELOD-2. Nilai cut-off masing-masing profil lipid berdasarkan kurva ROC. Hubungan antara profil lipid dan derajat keparahan penyakit dianalisis dengan uji chi-square atau Fisher exact. Nilai $p<0,05$ dianggap bermakna secara statistik . Hasil. Dari kurva ROC didapatkan nilai cut-off kadar kolesterol total dan trigliserida 93,5 mg/dL dan 199 mg/dL, dan nilai cut-off untuk kadar HDL dan LDL adalah 20,5 mg/dL dan 48,5 mg/dL. Didapatkan hubungan profil lipid dan derajat keparahan penyakit (PELOD-2) dengan nilai p: kolesterol total 0,007, trigliserida 0,005, HDL 0,063 dan LDL 0,279.

Kesimpulan. Terdapat hubungan bermakna antara kadar kolesterol total dan trigliserida dengan derajat keparahan penyakit berdasarkan skor PELOD-2. Tidak terdapat hubungan bermakna antara HDL dan LDL dengan derajat keparahan penyakit berdasarkan skor PELOD-2. Sari Pediatri 2019;20(5):289-94

Kata kunci: kolesterol total, trigliserida, HDL, LDL, PELOD-2

\section{Association between Lipid Profile and Severity of Disease based on Pediatric Logistic Organ Dysfunction-2 Score in Pediatric Sepsis}

Rince Restiviona, Chairul Yoel, Pertin Sianturi

Background. Sepsis is the most common cause of mortality in neonates and children in the hospital. Sepsis and septic shock may lead to neuro-endocrine and metabolic alterations including plasma lipid and lipoprotein. But the association between lipid profile and severity of disease in pediatric sepsis is still unclear.

Objective. To investigate the association between lipid profile and severity of disease in pediatric sepsis.

Methods. A cross-sectional study was conducted from July to October 2017 in PICU, Haji Adam Malik hospital. The samples were included children from one month to $<18$ year old who diagnosed with sepsis. Patients who suffered from diabetes mellitus, nephrotic syndrome, overweight, severe malnutrition, received statin and parenteral lipid was excluded. There were 30 children included this study. The severity of disease was examined by using PELOD-2 score. Cut-off points for each lipid profile based on Receiver Operating Characteristic (ROC) curves. The association between lipid profile and severity of disease was analyzed using chi-square or Fisher exact test. The $\mathrm{P}$ value $<0,05$ was considered to be statistically significant.

Results. The cut-off point based on ROC curve for total cholesterol was $93.5 \mathrm{mg} / \mathrm{dL}$, triglyceride $199 \mathrm{mg} / \mathrm{dL}, \mathrm{HDL} 20.5 \mathrm{mg} / \mathrm{dL}$ and LDL $48.5 \mathrm{mg} / \mathrm{dL}$. The association between lipid profile and severity of disease (PELOD-2 score) had P values as follows: total cholesterol 0,007, triglyceride 0,005 HDL 0,063 and LDL 0,279.

Conclusion. The association between total cholesterol and triglyceride with a severity of disease in pediatric sepsis were statistically significant. No association between HDL and LDL with a severity of disease in pediatric sepsis were statistically significant. Sari Pediatri 2019;20(5):289-94

Keywords: total cholesterol, triglyceride, HDL, LDL, PELOD-2 score

Alamat korespondensi: Rince Restiviona. Departemen Ilmu Kesehatan Anak Fakultas Kedokteran Universitas Sumatera Utara, Jl. Dr. Mansyur No. 66, Medan 20154.. Email: restivionarince@gmail.com 
Rince Restiviona dkk: Hubungan profil lipid dan derajat keparahan penyakit berdasarkan skor PELOD-2 pada sepsis

S epsis merupakan masalah kesehatan yang menjadi penyebab kematian terbanyak pada bayi dan anak di rumah sakit. ${ }^{1}$ Sepsis adalah disfungsi organ yang mengancam kehidupan (life-threatening organ dysfunction) yang disebabkan oleh disregulasi imun terhadap infeksi. ${ }^{2}$ Diperkirakan lebih dari 750.000 kasus sepsis di Amerika Serikat dengan 200.000 kematian per tahun. ${ }^{3}$ Secara umum, mortalitas sepsis berat sebanyak 30\% dan syok septik 50\%-60\%. ${ }^{4}$ Di unit perawatan intensif anak Rumah Sakit Cipto Mangunkusumo (RSCM) 19,3\% dari 502 pasien yang dirawat mengalami sepsis dengan angka mortalitas $54 \%{ }^{2}$

Profil lipid adalah pola gambaran lipid darah yang terdiri dari kolesterol total, trigliserida, low-density lipoprotein (LDL) dan high-density lipoprotein (HDL). ${ }^{5}$ Perubahan konsentrasi dan komposisi lipid plasma serta lipoprotein terjadi pada infeksi akut, inflamasi, sepsis dan syok septik. ${ }^{6}$ Pada kondisi sepsis terjadi perubahan neuroendokrin dan metabolik seperti peningkatan konsentrasi kortisol serum, hormon tiroid rendah, resistensi insulin, peningkatan kadar glukosa, laktat, kadar asam lemak bebas, trigliserida dan penurunan HDL. ${ }^{78}$ Perubahan ini diperantarai oleh sitokin seperti interleukin-1 (IL-1) dan tumor necrosis factor- $\alpha$ (TNF- $\alpha$ ) yang terlibat dalam respon

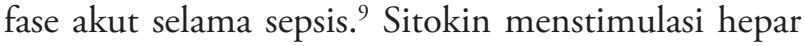
untuk meningkatkan sintesa trigliserida, mengurangi kolesterol plasma dan apolipoprotein, khususnya HDL kolesterol. ${ }^{6,10}$

Penelitian mengenai kadar lipid serum dan derajat berat penyakit atau kematian pada pasien sepsis masih terbatas pada pasien dewasa. Penelitian di Iran membandingkan kadar kolesterol total, HDL, LDL dan trigliserida pada pasien sepsis dan non sepsis. Didapatkan kadar kolesterol total, HDL, LDL lebih rendah pada pasien sepsis. Namun tidak terdapat perubahan bermakna pada kadar trigliserida. ${ }^{8}$ Penelitian pada pasien dewasa di Korea (2008) didapatkan kadar kolesterol, trigliserida, HDL dan LDL dan Apolipoprotein (Apo) A-1 pada hari 0,1,3 dan 7 lebih rendah pada pasien sepsis yang meninggal. ${ }^{11}$ Penelitian profil lipid pada anak dengan sepsis masih sangat terbatas. Penelitian lipid plasma pada anak dengan sepsis meningococcal yang dirawat di Pediatric Intensive Care Unit (PICU) didapatkan kadar kolesterol total, HDL dan LDL saat pertama dirawat berhubungan terbalik dengan tingkat keparahan penyakit. ${ }^{10}$
Di Indonesia, sampai saat ini baru satu penelitian di Rumah Sakit Cipto Mangunkusumo (RSCM) tahun 2011 yang meneliti mengenai hubungan antara HDL dengan skor Pediatric Logistic Organ Dysfunction (PELOD) pada anak sepsis. ${ }^{12}$ Namun, penelitian mengenai profil lipid yang lengkap pada pasien anak dengan sepsis belum ada. Hal inilah yang menjadi latar belakang dilakukan penelitian untuk mengetahui hubungan profil lipid terhadap derajat keparahan penyakit pada anak dengan sepsis yang dirawat di Rumah Sakit Umum Pusat (RSUP) Haji Adam Malik Medan. Tujuan penelitian ini adalah untuk menilai hubungan antara propil lipid dengan derajat keparahan penyakit berdasarkan skor PELOD-2 pada pasien anak dengan sepsis.

\section{Metode}

Sebuah penelitian analitik observasional yang menggunakan desain potong-lintang yang dilakukan pada anak dengan sepsis usia 1 bulan sampai kurang dari 18 tahun di unit perawatan intensif anak RSUP Haji Adam Malik Medan bulan Juli - Oktober 2017. Subjek dikumpulkan secara consecutive sampling. Pasien yang menderita diabetes melitus, sindrom nefrotik, gizi lebih, gizi buruk, mendapatkan terapi statin dan insulin tidak diikutsertakan dalam penelitian. Kriteria sepsis ditegakkan apabila skor PELOD-2 $\geq 7 .{ }^{2}$ Profil lipid adalah nilai kolesterol total, trigliserida, HDL, LDL yang didapat dari pengambilan sampel darah vena diperiksa dengan menggunakan mesin ARCHITECT c system. Derajat keparahan penyakit dinilai berdasarkan skor PELOD-2 dan diklasifikasikan menjadi derajat ringan-sedang (PELOD-2 $\leq 9)$ dan derajat berat $($ PELOD-2 $>9) .{ }^{2}$ Status gizi lebih dinilai berdasarkan indeks masa tubuh (IMT) berada pada persentil $85^{\text {th }}$ $95^{\text {th }} \cdot{ }^{13}$ Gizi buruk dinilai berdasarkan berat badan (BB) aktual/BB ideal menurut Waterlow $<70 \%$ atau pada kurva World Health Organization (WHO) 2006 BB/ TB berada pada $\mathrm{Z}$ score $\leq-3$ atau lingkar lengan atas (LILA) $<110 \mathrm{~mm}^{14}$

Sampel darah anak yang menderita sepsis yang memenuhi kriteria diambil pada saat masuk. Dilakukan penilaian PELOD-2 dan pemeriksaan laboratorium meliputi darah rutin, C-reactive protein (CRP), prokalsitonin, fungsi ginjal, analisis gas darah (AGDA), kultur darah dan profil lipid. Semua subjek penelitian mendapat persetujuan dari orang tua setelah dilakukan 
penjelasan terlebih dahulu mengenai kondisi penyakit yang dialami dan pemeriksaan yang akan dilakukan. Penelitian ini disetujui oleh Komite Etik Penelitian Fakultas Kedokteran Universitas Sumatera Utara.

Nilai cut-off untuk kolesterol total, trigliserida, HDL dan LDL didapat berdasarkan kurva Receiver Operating Characteristic (ROC). Kemudian dilakukan analisis bivariat untuk menilai hubungan profil lipid dengan derajat keparahan penyakit berdasarkan skor PELOD-2 dengan menggunakan uji chi-square jika syarat uji terpenuhi, atau fisher exact test. Analisis statistik dilakukan dengan menggunakan SPSS versi 20. Nilai $\mathrm{p}<0.05$ dianggap bermakna secara statistik.

\section{Hasil}

Selama penelitian di unit perawatan intensif anak di RSUP Haji Adam Malik Medan mulai bulan Juli sampai Oktober 2017 ada 30 orang pasien anak dengan sepsis yang berusia 1 bulan sampai kurang dari 18 tahun yang memenuhi kriteria.

Tabel 2 menunjukkan rerata hasil laboratorium subjek penelitian. Didapatkan sebagian besar subjek penelitian dengan kadar leukosit yang meningkat dan prokalsitonin yang meningkat. Sementara rerata kadar profil lipid diperoleh kolesterol total $97,0 \mathrm{mg} /$ $\mathrm{dL}$, trigliserida $157,9 \mathrm{mg} / \mathrm{dL}$, HDL $26,9 \mathrm{mg} / \mathrm{dL}$ dan LDL 44,7 mg/dL. Dari kurva ROC didapatkan nilai cut-off kadar kolesterol total dan trigliserida $93,5 \mathrm{mg} /$ dL dan 199 mg/dL, dan nilai cut-off untuk kadar HDL dan LDL adalah $20,5 \mathrm{mg} / \mathrm{dL}$ dan $48,5 \mathrm{mg} / \mathrm{dL}$.

Tabel 1. Karakteristik demografik subjek penelitian

\begin{tabular}{lc}
\hline Variabel & Hasil \\
\hline Jenis kelamin & \\
Laki-laki (n) & 19 \\
Perempuan (n) & 11 \\
Usia, tahun, rerata (SB) & $3,8(4,60)$ \\
Status gizi & \\
Baik (n) & 22 \\
Kurang (n) & 8 \\
PELOD-2 & \\
PELOD-2 $\leq 9$ derajat ringan-sedang (n) & 18 \\
PELOD-2 >9 derajat berat (n) & 12 \\
Kultur darah & \\
Positif (n) & 5 \\
$\quad$ Negatif (n) & 25 \\
\hline
\end{tabular}

Tabel 2. Hasil laboratorium subjek penelitian

\begin{tabular}{lc}
\hline Variabel & Hasil rerata $(\mathrm{SB})$ \\
\hline Leukosit, $/ \mu \mathrm{L}$ & $18148(10589)$ \\
Prokalsitonin, ng/mL & $50,8(39,56)$ \\
Kolesterol total, mg/dL & $97,0(37,30)$ \\
Trigliserida, mg/dL & $157,9(73,33)$ \\
HDL, mg/dL & $26,9(26,35)$ \\
LDL, mg/dL & $44,7(30,56)$ \\
\hline
\end{tabular}

Tabel 3. Hubungan profil lipid dengan skor PELOD-2

\begin{tabular}{|c|c|c|c|}
\hline \multirow{2}{*}{$\begin{array}{l}\text { Profil lipid } \\
(\mathrm{mg} / \mathrm{dL})\end{array}$} & \multicolumn{2}{|c|}{$\begin{array}{c}\text { PELOD-2 } \\
\text { (Derajat keparahan penyakit) }\end{array}$} & \multirow{2}{*}{ Nilai p } \\
\hline & $\begin{array}{c}>9 \\
\text { (Derajat berat) }\end{array}$ & $\begin{array}{c}\leq 9 \\
\text { (Derajat ringan-sedang) }\end{array}$ & \\
\hline \multicolumn{4}{|l|}{ Kolesterol } \\
\hline$\leq 93,5$ & 10 & 6 & $0,007^{a}$ \\
\hline$>93,5$ & 2 & 12 & \\
\hline \multicolumn{4}{|l|}{ Trigliserida } \\
\hline$<199$ & 6 & 17 & $0,005^{\mathrm{b}}$ \\
\hline$\geq 199$ & 6 & 1 & \\
\hline \multicolumn{4}{|l|}{ HDL } \\
\hline$\leq 20,5$ & 10 & 9 & $0,063^{\mathrm{b}}$ \\
\hline$>20,5$ & 2 & 9 & \\
\hline \multicolumn{4}{|l|}{ LDL } \\
\hline$\leq 48,5$ & 9 & 10 & $0,279^{\mathrm{b}}$ \\
\hline$>48,5$ & 3 & 8 & \\
\hline
\end{tabular}




\section{Pembahasan}

Infeksi dan inflamasi menyebabkan perubahan kadar lipid plasma dan lipoprotein akibat pelepasan sitokin. Beberapa penelitian sebelumnya melaporkan pada pasien dengan infeksi terjadi penurunan kadar kolesterol total, HDL dan LDL serta peningkatan kadar trigliserida. ${ }^{15}$ Namun, penelitian yang menilai hubungan profil lipid pada anak dengan derajat keparahan penyakit berdasarkan skor PELOD-2 belum pernah dipublikasi.

Dari 30 sampel, didapatkan hasil kultur darah positif $16,7 \%$ yang terdiri dari kuman Gram negatif (Klebsiella pneumonia, Ralstonia mannitolilytica dan Proteus hauseri) dan kuman Gram positif (Enterococcus faecium, Staphylococcus aureus). Penelitian lain di ICU dewasa, didapatkan kultur darah positif $28,7 \%$ dari 70 sampel dengan kuman terbanyak adalah Klebsiella pneumonia (10\%) dan Staphylococcus aureus $(8,8 \%) .^{15}$ Demikian juga penelitian pada pasien sepsis di Iran didapatkan kultur darah positif 38,4\% dari 26 pasien sepsis dengan kuman terbanyak adalah Gram negatif (Klebsiella pneumonia dan E.coli). ${ }^{16}$

Kadar trigliserida pasien dengan sepsis dan SIRS meningkat dan kadar HDL, LDL dan very-low-density lipoprotein (VLDL) menurun dalam 24 jam pertama. Perubahan ini terjadi selama 72 jam dan akan kembali normal setelah lebih dari 7 hari. ${ }^{17}$ Pasien dengan sepsis berat, kolesterol total dan HDL akan kembali mencapai kadar pemulihan 50\% pada hari ketiga. ${ }^{15}$ Pada penelitian ini, fluktuasi kadar profil lipid tidak dapat dinilai karena pemeriksaan profil lipid hanya dilakukan satu kali pada saat pasien masuk.

Kami mendapatkan lebih banyak sampel dengan kadar kolesterol $\leq 93,5 \mathrm{mg} / \mathrm{dL}$ pada sepsis berat. Sebaliknya lebih banyak sampel dengan kadar kolesterol $>93,5 \mathrm{mg} / \mathrm{dL}$ pada sepsis ringan-sedang. Hasil uji statistik menyatakan perbedaan tersebut bermakna. Hal ini sesuai dengan beberapa penelitian sebelumnya yang melaporkan adanya hubungan kadar kolesterol yang rendah dan sepsis. ${ }^{15}$ Penelitian di Jepang, pada pasien dewasa dengan kultur darah positif didapatkan mortalitas lebih tinggi pada pasien dengan kadar kolesterol lebih rendah (nilai cut-off $143 \mathrm{mg} / \mathrm{dL}$ ) dengan nilai $\mathrm{p}=0,04 .{ }^{18}$ Demikian juga penelitian yang dilakukan pada pasien infeksi di Jerman, didapatkan angka mortalitas lebih tinggi $(82 \%)$ pada kadar kolesterol $\leq 50 \mathrm{mg} / \mathrm{dL}$ dibandingkan kadar kolesterol $\geq 100 \mathrm{mg} / \mathrm{dL}$ (angka mortalitas hanya
21\%). Namun pada penelitian kami tidak dilakukan penilaian hubungan profil lipid dan mortalitas pada pasien sepsis.

Mekanisme yang menjelaskan penurunan kadar kolesterol masih belum jelas. ${ }^{19}$ Namun demikian, hipokolesterolemia yang berat pada sepsis berhubungan langsung dengan respon fase akut. Infeksi akut dan kronik akibat bakteri, virus dan parasit dapat menyebabkan hipokolesterolemia akibat pengaruh sitokin proinflamasi pada metabolisme lipoprotein. ${ }^{9}$ Hipokolesterolemia berat kadang-kadang dihubungkan dengan hipertrigliseridemia yang terjadi khususnya pada pasien sepsis dengan dekompensasi metabolik dan keadaan preterminal. ${ }^{20}$

Berbagai penelitian mengenai trigliserida pada sepsis telah dilakukan, kadar trigliserida dapat tinggi atau rendah pada sepsis. ${ }^{15}$ Pada penelitian kami didapatkan lebih banyak sampel sepsis berat dengan kadar trigliserida $\geq 199 \mathrm{mg} / \mathrm{dL}$, sedangkan lebih banyak sampel sepsis ringan-sedang dengan kadar trigliserida $<199 \mathrm{mg} / \mathrm{dL}$. Berdasarkan hasil uji statistik didapatkan hubungan tersebut bermakna. Hal tersebut sesuai dengan penelitian lain pada pasien sepsis dewasa, dilaporkan kadar trigliserida $\geq 150 \mathrm{mg} /$ dL pada pasien sepsis (16,7\%), syok sepsis $(30,8 \%)$ dan sepsis berat (48,5\%). Kadar trigliserida $\geq 150 \mathrm{mg} /$ dL memiliki mortalitas yang lebih tinggi $(45,8 \%)$ dibandingkan pasien dengan kadar trigliserida $<150$ $\mathrm{mg} / \mathrm{dL}$ (mortalitas 17,4\%). ${ }^{15}$ Kadar trigliserida yang meningkat merupakan perubahan metabolik awal pada infeksi akibat pengaruh sitokin pada respon fase akut. ${ }^{21}$ Kadar endotoksin yang tinggi terutama pada sepsis berat akan menekan aktivitas lipoprotein lipase (LPL) sehingga mengakibatkan kadar trigliserida meningkat. ${ }^{22}$ Berbeda dengan hasil penelitian di Iran yang melaporkan, bahwa kadar trigliserida lebih rendah pada pasien dengan infeksi bakteri akut dibandingkan kontrol, tetapi hal ini tidak bermakna secara statistik. ${ }^{23}$ Penelitian tersebut tidak menilai hubungan trigliserida dengan derajat keparahan sepsis. Demikian juga dengan penelitian pasien sepsis di Korea pada hari 013 dan 7 didapatkan kadar trigliserida lebih tinggi pada pasien yang hidup dibandingkan yang meninggal dan perbedaan ini bermakna pada hari 0 dan $1 .{ }^{11}$ Perbedaan hasil penelitian ini kemungkinan disebabkan perbedaan penilaian derajat sepsis yang digunakan. Pada penelitian kami digunakan skor PELOD-2, sedangkan pada penelitian di Korea digunakan mortalitas untuk menilai keparahan sepsis. 
Demikian juga dengan HDL, penelitian kami mendapatkan kadar HDL $\leq 20,5 \mathrm{mg} / \mathrm{dL}$ lebih banyak pada sepsis berat sedangkan pada sepsis ringan-sedang lebih banyak sampel dengan kadar HDL >20,5 mg/dL. Namun hubungan kadar HDL dan derajat keparahan sepsis tidak bermakna secara statistik. Hal tersebut sama dengan penelitian pada pasien anak sepsis di RSCM yang melaporkan bahwa semakin rendah kadar HDL (dengan nilai cut-off $20 \mathrm{mg} / \mathrm{dL}$ ) maka skor PELOD semakin tinggi. ${ }^{12}$ Penelitian pada pasien sepsis berat dewasa di Manipal juga melaporkan adanya hubungan korelasi negatif antara HDL saat masuk dengan Acute Physiologi and Chronic Health Evaluation (APACHE) II, skor APACHE II meningkat bersamaan dengan penurunan kadar HDL. ${ }^{24}$ Demikian juga penelitian di Taiwan (2005) yang melaporkan bahwa kadar HDL rendah pada sepsis berat (hari pertama rawatan) berhubungan bermakna dengan peningkatan mortalitas dan outcome klinis. ${ }^{25}$ Kadar HDL yang rendah berkorelasi negatif dengan keparahan sepsis, hal ini berhubungan dengan respon inflamasi yang berlebihan. ${ }^{22}$ Pada pasien sepsis berat, HDL menurun secara cepat akibat peningkatan kadar secretory phospholipase A2 (sPLA2) dan Serum Amyloid A (SAA) menggantikan Apo-A1. ${ }^{26,27}$ Mekanisme penting lain yang menyebabkan menurunnya HDL berkaitan dengan substansi bakteri khususnya lipopolysaccharide (LPS) dan endotoksin lain. Kolesterol dan lipoprotein memperantarai pelepasan LPS melalui detoksifikasi, pembentukan kompleks dan netralisasi efek toksin. ${ }^{8}$

Penelitian pada pasien anak sepsis meningococcal dan syok sepsis didapatkan kadar kolesterol total, HDL dan LDL saat masuk berkorelasi terbalik dengan keparahan penyakit dan kadar kortisol. ${ }^{10}$ Pada penelitian, kami dapatkan lebih banyak sampel dengan kadar $\mathrm{LDL} \leq 48,5 \mathrm{mg} / \mathrm{dL}$ pada sepsis berat dan sepsis ringan sedang, tetapi hal ini tidak bermakna secara statistik. Penelitian lain di Iran (2011) yang dilakukan pada pasien sepsis dewasa didapatkan kadar LDL, HDL dan kolesterol lebih rendah pada pasien sepsis dibandingkan nonsepsis pada hari 0 dan 10. Namun perbedaan ini tidak bermakna antara pasien yang hidup dan yang meninggal. ${ }^{8}$ Penelitian yang dilakukan pada pasien sepsis dewasa di Kerala (2013), menyatakan LDL $(<100 \mathrm{mg} / \mathrm{dL})$ dan mortalitas berhubungan bermakna $(\mathrm{p}=0,02) \cdot{ }^{15}$ Demikian juga penelitian di Swedia yang membandingkan antara kelompok pasien dengan Systemic Inflammatory Response syndrome (SIRS), sepsis, syok septik dan sepsis berat dengan kontrol, didapatkan kadar LDL, HDL dan kolesterol paling rendah pada pasien sepsis berat diikuti syok sepsis, sepsis dan SIRS dibandingkan dengan kontrol. ${ }^{28}$. Pada penelitian pasien anak dan dewasa dengan sepsis keduanya memiliki hubungan terbalik antara kolesterol total, HDL dan LDL dengan keparahan penyakit (mortalitas).

Di beberapa negara seperti Denmark, United Kingdom, Eropa, Kanada, Brazil, dan Amerika Serikat telah menyatakan menggunakan pemeriksaan profil lipid dalam keadaan tidak puasa. Berdasarkan penelitian terhadap kadar profil lipid pada sampel darah puasa dan tidak puasa didapatkan, rerata perubahan kadar trigliserida $+26 \mathrm{mg} / \mathrm{dL}(0,3 \mathrm{mmol} / \mathrm{L})$, kolesterol total $-8 \mathrm{mg} / \mathrm{dL}(0,2 \mathrm{mmol} / \mathrm{L}), \mathrm{HDL}-8 \mathrm{mg} / \mathrm{dL}(0,2 \mathrm{mmol} / \mathrm{L})$ dan LDL $-8 \mathrm{mg} / \mathrm{dL}(0,2 \mathrm{mmol} / \mathrm{L})$. Namun demikian perubahan ini tidak bermakna secara klinis. ${ }^{18}$

Kelebihan penelitian ini adalah nilai cut-off didapatkan berdasarkan kurva ROC dan penelitian ini menilai hubungan masing-masing komponen profil lipid dengan derajat keparahan penyakit. Kelemahan penelitian ini adalah pengambilan sampel tidak dilakukan secara berkala.

\section{Kesimpulan}

Terdapat hubungan bermakna antara kolesterol total dan trigliserida dengan derajat keparahan penyakit berdasarkan skor PELOD-2, sedangkan HDL dan LDL tidak terdapat hubungan bermakna.

\section{Daftar pustaka}

1. Hotchkiss RS, Karl IE. The pathophysiology and treatment of sepsis. N Engl J Med 2003;139-48.

2. Latief A, Chairulfatah A, Alam A, Pudjiadi AH, Malise RF, Hadinegoro SRS. Diagnosis dan tata laksana sepsis pada anak. Jakarta: Badan Penerbit Ikatan Dokter Anak Indonesia. 2016.h.1-34.

3. Das UN. Role of lipids in sepsis. Crit Care \& Shock 2004; 7:87-92.

4. Widodo AD, Tumbelaka AR. Penggunaan steroid dalam tata laksana sepsis analisis kasus berbasis bukti. Sari Pediatri 2010; 11:387-94

5. Mulia S, Iriani Y, Anwar Z, Theodorus. Profil lipid pada fase akut demam berdarah dengue. J Kedokt dan Kesehatan 2014;1:13-9.

6. Wu A, Hinds CJ, Thiemermann C. High-Density lipoproteins 
Rince Restiviona dkk: Hubungan profil lipid dan derajat keparahan penyakit berdasarkan skor PELOD-2 pada sepsis

in sepsis and septic shock: metabolism, actions and therapeutic application. SHOCK 2004; 21:210-21.

7. Joosten KFM, Kleijn EDDE, Westerterp M, Hoog MDE, Eijck FCV, Hop WCJ. Endocrine and metabolic responses in children with meningococcal sepsis: stricking differences between survivors and nonsurvivors. J Clin Endocrinol Metab 85;2000;1-8.

8. Barati M, Nazari MZ, taher MT, Farhadi N. Comparison of lipid profile in septic and non-septic patients. Iran J Clin Infect Dis 2011;6:144-6.

9. RR Elmehdawi. Hypolipidemia: a word of caution. Libyan J Med 2008;3:84-90.

10. Vermont CL, Den Brinker M, Kakeci N, De Kleijn ED, De Rijke YB, Joosten KFM, dkk. Serum lipids and disease severity in children with severe meningococcal sepsis. Crit Care Med 2005;33:1610-15.

11. Lee SH, Park MS, Park BH, Jung WJ, Lee IS, Kim SY dkk. Prognostic implications of serum lipid metabolism over time during sepsis. Bio Med Res Int 2015;1-8. doi:10.1155/2015/789298.

12. Yulianti E, Pudjiadi AH, Said M, Suyoko EMD, Satari HI, Gayatri P. Hubungan antara kadar high density lipoprotein dengan derajat sepsis berdasarkan skor Pediatric logistic organ dysfunction. Sari Pediatri 2013;15:116-21.

13. Sjarif DR. Prinsip asuhan nutrisi pada anak. Dalam: Sjarif DR, Lestari ED, Mexitalia M, Nasar SS, penyunting. Buku ajar nutrisi pediatrik dan penyakit metabolik Jilid I. Jakarta: Badan Penerbit Ikatan Dokter Anak Indonesia; 2011. h. 37-9.

14. Susanto JC, Mexitalia M, Nasar SS. Malnutrisi akut berat dan terapi nutrisi berbasis komunitas. Dalam: Sjarif DR, Lestari ED, Mexitalia M, Nasar SS, penyunting. Buku ajar nutrisi pediatrik dan penyakit metabolik. Edisi pertama. Jakarta: Badan Penerbit Ikatan Dokter Anak Indonesia; 2011.h.128-9.

15. Sunayana P, Renymol B, Ambili NR. Fasting lipid profile and disease severity in sepsis patients. J Clin Diag Res 2017; 11:10-12.

16. Mausavi SAJ, Adell SH, Zahedi L. Determination of association between the decrease in cholesterol concentration and sepsis in patients admitted in the ICU. Tanaffos 2003;2:11-16.

17. Muramato G, Delgado AF, De Souza EC, Gilio AE, De Carvalho WB, Maranhao RC. Lipid profiles of children and adolescents with inflammatory response in a paediatric emergency department. Ann Med 2016;1-6.

18. Kitazawa T, Yanagimoto S, Tatsuno K, Fukushima A, Okugawa S, dkk. Serum cholesterol levels at the onset of bloodstream infection have prognostic value. Advances in Infect Dis 2012;2:100-5.

19. Biller K, Fae P, Germann R, Drexel H, Walli AK, Fraunberger P. Cholesterol rather than procalsitonin or C-reactive protein predicts mortality in patients with infection. Shock 2014; 42:129-32.

20. Chiarla C, Giovannini I, Guiliante F, Zadak Z, Vellone M, Ardito F, dkk. Severe hypocholesterolemia in surgical patients, sepsis, and critical illness. J Crit Care 2010;25:361.e7-12.

21. Khovidhunkit W, Kim M-S, Memon RA, Shigenaga JK, Moser $\mathrm{AH}, \mathrm{dkk}$. Effects of infection and inflammation on lipid and lipoprotein metabolism: mechanisms and consequences to the host. J Lipid Res 2004;45:1169-96.

22. Wendel M, Paul R, Heller AR. Lipoproteins in inflammation and sepsis. Intensive Care Med 2007;33:25-35.

23. Nasaji M. Ghorbani R. Plasma lipid level in patients with acute bacterial infections. Turk J Med Sci 2012;42:465-9.

24. Monigari N, Vidyasagar S, Elagandula J. Study of serum HDL levels in severe sepsis patients in medical intensive care unit. Int J Sci Res Pub 2015;5:1-13.

25. Bonville DA, Parker TS, Levine DM, Gordon BR, Hydo LJ, Eachempati SR, dkk. The relationships of hypocholesterolemia to cytokine concentrations and mortality in critically Ill patients with systemic inflammatory response syndrome. Surg Infect 2004;5:39-49.

26. Van Leeuwen HJ, Heezius ECJM, Dallinga GM, Van Strijp JAG, Verhoef J, dkk. Lipoprotein metabolism in patients with severe sepsis. Crit Care Med 2003;31:1359-66.

27. Pirillo A, Catapano AL, Norata GD. HDL in infectious disease and sepsis. Dalam: Von Eckardstein A, Kardassis D, penyunting. Handbook of experimental pharmacology. Springer; 2015.h.483-508.

28. Kumaraswarny SB, Linder A, Per Akesson, Dahlback B. Decreased plasma concentrations of apolipoprotein $\mathrm{M}$ in sepsis and systemic inflammatory response syndromes. Crit Care 2012;16:1-7. 